\title{
PENERAPAN MODEL PEMBELAJARAN TUTOR SEBAYA UNTUK MENINGKATKAN HASIL BELAJAR MATEMATIKA SISWA KELAS V SEMESTER GENAP SD NEGERI 5 SUBAGAN TAHUN PELAJARAN 2016/2017
}

\author{
NI WAYAN EKA JUNIANTARI \\ SD Negeri 5 Subagan \\ Email: wayanekajuniantari19@gmail.com
}

\begin{abstract}
ABSTRAK
Penelitian ini untuk mengetahui peningkatan hasil belajar Matematika setelah diterapkan model pembelajaran tutor sebaya siswa kelas V semester genap SD Negeri 5 Subagan tahun pelajaran 2016/2017.Penelitian ini adalah penelitian tindakan kelas yang dilaksanakan dalam dua siklus. Subjek penelitian adalah siswa kelas V semester genap SD Negeri 5 Subagan tahun pelajaran 2016/2017, sebanyak 33 orang. Pengumpulan data dalam penelitian ini dilakukan dengan metode tes. Data yang telah didapatkan selanjutnya dianalisis dengan menggunakan metode analisis deskriptif kuantitatif. Hasil penelitian penerapan model pembelajaran tutor sebaya menunjukkan bahwa terjadi peningkatan rata-rata hasil belajar agama Hindu dari siklus I ke siklus II sebesar 17,42 pada siklus I mencapai 66,52dengan kategori cukup dan pada siklus II mencapai 83,94dengan kategori baik.
\end{abstract}

Kata Kunci: tutor sebaya, hasil belajar

\section{PENDAHULUAN}

Pendidikan adalah pengaruh, bimbingan, arahan dari orang dewasa kepada anak yang belum dewasa agar menjadi dewasa, mandiri dan memiliki kepribadian yang utuh dan matang" (Yahya, 2003). Kepribadian yang dimaksud adalah semua aspek yang ada sudah matang yaitu meliputi cipta, rasa, dan karsanya. Pendidikan sebagai proses pembentukkan pribadi diartikan sebagai suatu kegiatan yang sistematis dan sistemik terarah kepada terbentuknya kepribadian peserta didik (Tirtarahardja dan La Sulo, 1994). Pendidikan dikatakan sistematis karena proses pendidikan melalui tahap-tahap berkesinambungan. Pendidikan sistemik karena berlangsung di semua lingkungan baik lingkungan rumah, sekolah, maupun masyarakat.

Tirtarahardja dan La Sulo (1994) juga mengatakan bahwa, proses pembentukan pribadi dilakukan bagi orang yang belum dewasa oleh orang yang sudah dewasa, dan bagi orang yang sudah dewasa atas usaha sendiri. Salah satu contohnya adalah bayi yang baru lahir. Bayi yang baru lahir kepribadiannya belum terbentuk. Untuk menjadi suatu pribadi yang utuh, mereka perlu bimbingan, latihan dan pengalaman melalui bergaul dengan lingkungannya, khususnya dengan lingkungan pendidikan. Begitu pula dengan orang dewasa harus tetap dituntut adanya perkembangan diri agar kualitas kepribadian meningkat serentak dengan meningkatnya tantangan hidup yang selalu berubah.

Garis Besar Haluan Negara tahun 1988 (dalam Tirtarahardja dan La Sulo, 1994) menyatakan pengertian pendidikan nasional sebagai berikut. Pendidikan nasional yang berakal pada kebudayaan bangsa Indonesia dan berdasarkan Pancasila dan Undang-Undang Dasar 1945 diarahkan untuk meningkatkan kecerdasan serta harkat dan martabat bangsa, mewujudkan manusia serta masyarakat Indonesia yang beriman dan bertakwa kepada Tuhan Yang Maha Esa berkualitas, mandiri sehingga mampu membangun dirinya dan masyarakat sekelilingnya serta dapat memenuhi kebutuhan pembangunan nasional dan bertanggung jawab atas pembangunan bangsa.

Berdasarkan pandangan di atas, pendidikan merupakan pengaruh untuk membentuk pribadi dengan selalu menanamkan nilai-nilai. Termasuk nilai moral, budi pekerti, etika, estetika, dan karakter yang diarahkan untuk mampu membangun dirinya dan masyarakat sekelilingnya serta dapat memenuhi kebutuhan pembangunan nasional dan bertanggung jawab atas pembangunan bangsa. Selain itu, pendidikan nasional juga berkaitan erat dengan kebudayaan Indonesia. Hal ini disebabkan pendidikan nasional Indonesia berakal pada 
kebudayaan bangsa Indonesia dan tidak akan terlepas dari nilai-nilai kebudayaan yang dijunjung tinggi oleh semua lapisan masyarakat. Nilai-nilai kebudayaan bangsa Indonesia yang dikenal saat ini sudah menjadi karakter dari bangsa Indonesia yang membedakannya dengan bangsa lain. Karakter-karakter inilah yang ditanamkan pada siswa melalui pendidikan formal di sekolah.

Kebiasaan mencontek, tawuran antar pelajar, korupsi yang sulit diberantas, konflik, dan kekerasan di mana-mana merupakan sebuah fakta krisisnya kondisi karakter bangsa Indonesia. Dalam rangka mengatasi masalah tersebut maka pendidikan karakter bangsa diyakini sebagai obat mujarab. Pendidikan karakter memunculkan konsep kearifan lokal (local wisdom) yang dianggap sebagai modal kultural yang amat penting bagi pembentukkan karakter bangsa (Atmadja, 2012).

Mengingat begitu pentingnya Matematika di sekolah dan kegunaan Matematika dalam kehidupan sehari-hari maka suatu strategi pembelajaran yang tepat sangat diperlukan agar tujuan dapat dicapai sesuai yang diinginkan. Dari manfaat Matematika yang diberikan, seyogyanya Matematika disenangi dan diminati oleh siswa. Akan tetapi pada kenyataannya di lapangan, siswa masih menjadikan mata pelajaran Matematika suatu mata pelajaran yang membosankan dibandingkan dengan mata pelajaran yang lainnya. Motivasi sebagian siswa masih tergolong rendah dan mempengaruhi hasil belajar di kelas. Permasalahan yang diungkapkan di atas harus dipecahkan. Hal tersebut dikarenakan kurangnya motivasi belajar siswa yang akan mempengaruhi tingkat pencapaian hasil belajar siswa. Situasi demikian tergambar dalam proses pembelajaran Matematika kelas V di SD Negeri 5 Subagan.

Berdasarkan hasil observasi proses pembelajaran Matematika yang berlangsung di kelas V SD Negeri 5 Subagan pada hari Jumat,24 Februari 2017 dengan mengamati diperoleh beberapa masalah yaitu: (1) siswa kurang tertarik dengan pembelajaran Matematika terbukti dengan beberapa siswa terlihat mengantuk atau tidak bersemangat dalam proses pembelajaran di kelas, (2) siswa acap kali membuat alasan agar dapat keluar kelas, dan (3) jika diberikan latihan oleh guru siswa sering bekerja secara individual.

Berdasarkan hasil pencatatan dokumen diketahui bahwa nilai rata-rata ulangan harian siswaberturut-turut adalah 64,70, 65,00, dan 63,00. Ketiga nilai tersebut berada di bawah standar Kriteria Ketuntasan Minimal (KKM) yaitu 70. Hal tersebut ditunjukkan dari nilai ulangan harian siswa pada awal semester genap tahun ajaran 2016/2017.

Permasalahan tersebut, tampaknya diperlukan sebuah model pembelajaran yang inovatif dan mampu menumbuhkan hubungan sosial antar siswa sehingga hasil belajar siswa dapat ditingkatkan. Salah satunya dengan menerapkan model pembelajaran yang inovatif yang cocok digunakan dalam mata pelajaran Matematika adalah model pembelajaran tutor sebaya. "Di dalam model pembelajaran tutor sebaya (peer tutorial), yang menjadi guru adalah seorang teman sebaya di kelas bersangkutan, sedangkan yang menjadi siswa adalah siswa yang sebenarnya" (Sudhita, 2004). Dalam penerapan model ini, siswa yang biasanya malu bertanya kepada guru jika merasa kesulitan akan terbantu dengan bantuan tutor yang tiada lain adalah teman sekelasnya. Dengan demikian, hubungan sosial antara siswa dengan siswa juga dapat meningkat dengan penerapan model tutor sebaya.

Maka masalah yang dirumuskan dalam penelitian ini adalah apakah penerapan model pembelajaran tutor sebaya dapat meningkatkan hasil belajar siswa kelas V semester genap mata pelajaran Matematika SD Negeri 5 Subagan tahun pelajaran 2016/2017?

Penelitian ini bertujuan untuk mengetahui peningkatan hasil belajar siswa setelah diterapkan model pembelajaran tutor sebaya mata pelajaran Matematika kelas V semester genap SD Negeri 5 Subagan tahun pelajaran 2016/2017.Adapun manfaatnya yaitu baik secara praktis maupun teoritis sehingga hasil penelitian ini diharapkan dapat menjadi informasi berharga bagi kepala sekolah untuk mengambil suatu kebijakan yang paling tepat dalam kaitannya dengan model pembelajaran yang efektif dan efisien di sekolah. Matematika muncul dari suatu kehidupan nyata sehari-hari. Sebagai contoh pada kehidupan sehari hari pada dasarnya didapat dari benda-benda konkret dengan melakukan proses abstraksi dari benda- 
benda nyata. Oleh karena itu, proses pembelajaran Matematika harus dapat menghubungkan antara ide abstrak Matematika dengan situasi dunia yang nyata yang pernah dialami ataupun yang pernah dipikirkan siswa. Ausebel (dalam Winata Putra dan Suherman, 1993) menyatakan bahwa, dalam belajar Matematika siswa tidak hanya menerima dan menghafalkannya tetapi harus belajar secara bermakna. Belajar bermakna adalah proses belajar yang menghubungkan informasi atau pengetahuan yang sudah dimiliki siswa. Model pembelajaran adalah: "Kerangka konseptual yang melukiskan prosedur yang sistematis dalam mengorganisasikan pengalaman belajar untuk mencapai tujuan belajar tertentu, dan berfungsi sebagai pedoman bagi para perancang pembelajaran dan para pengajar dalam merencanakan aktivitas belajar mengajar". Model pembelajaran adalah suatu perencanaan atau suatu pola yang digunakan sebagai pedoman dalam merencanakan pembelajaran di kelas atau pembelajaran dalam tutorial dan untuk menemukan perangkat pembelajaran termasuk buku buku, film, komputer, kurikulum dan yang lainnya. Setiap model pembelajaran mengarahkan kita untuk mendesain pembelajaran untuk membantu peserta didik sedemikian rupa sehingga tujuan pembelajaran tercapai. Hal tersebut dikarenakan prestasi itu sendiri merupakan hasil belajar yang biasanya dinyatakan dengan nilai. Surahmad (dalam Dossuwanda, 2008) menyatakan bahwa hasil belajar adalah hasil bentuk akhir dari pengalaman interaksi edukatif yang diperhatikan dengan menempatkan tingkah laku. Suprijono (2009) menyatakan bahwa, "hasil belajar adalah pola-pola perbuatan, nilai-nilai, pengertian-pengertian, sikap-sikap, apresiasi dan keterampilan.

Model pembelajaran tutor sebaya adalah pembelajaran teman sebaya atau antar peserta didik. Syaifuddin (2007) menyatakan bahwa, "tutor sebaya merupakan salah satu model pengelompokkan siswa dalam pembelajaran". Pembelajaran yang menggunakan model pembelajaran tutor sebaya memanfaatkan siswa yang lebih pintar sebagai guru yang mengajarkan siswa lain yang belum paham. Model pembelajaran tutor sebaya secara tidak langsung menjadikan siswa lebih demokratis, bisa bekerja sama, dan tidak bersifat individual. Rumusan hipótesis yaitu dengan digunakan model pembelajaran tutor sebaya secara efektif dalam pembelajaran, maka hasil belajar siswa kelas $\mathrm{V}$ semester genap mata pelajaran Matematika SD Negeri 5 Subagan meningkat.

\section{METODE PENELITIAN}

Penelitian ini dilaksanakan pada semester genap tahun pelajaran 2016/2017. Penentuan waktu penelitian mengacu kepada kalender pendidikan SD Negeri 5 Subagan. Subjek penelitian ini adalah siswa kelas V semester genap SD Negeri 5 Subagan tahun pelajaran 2016/2017. Jumlah siswa yang menjadi subjek penelitian adalah 33 orang yang terdiri dari 16 orang laki-laki dan 17 orang perempuan Objek penelitian ini adalah peningkatan hasil belajar Matematika siswa kelas V di SD Negeri 5 Subagan tahun pelajaran 2016/2017. Penelitian tindakan kelas ini dilaksanakan di SD Negeri 5 Subagan Kecamatan Karangasem Kabupaten Karangasem tahun pelajaran 2016/2017 dalam mata pelajaran Matematika. Penelitian ini tergolong Penelitian Tindakan Kelas (Classroom Action Research). Penelitian tindakan sebagaimana dikemukakan oleh Kemmis dan Taggart (dalam Sukardi 2003:214) menggunakan empat komponen penelitian tindakan diantaranya adalah perencanaan, tindakan, observasi/evaluasi, dan refleksi dalam suatu sistem spiral yang saling terkait Dalam penelitian ini, pelaksanaan tindakan dilaksanakan dalam dua siklus. Masing-masing siklus pada penelitian tindakan direncanakan akan dilaksanakan tiga kali pertemuan dengan rincian dua kali untuk pelaksanaan tindakan dan satu kali untuk tes akhir siklus. Adapun rangkaian kegiatan penelitian tindakan pada siklus I diuraikan sebagai berikut. 1. Tahap perencanaan, 2. Tahap tindakan, 3. Tahap observasi dan evaluasi, 4. Refleksi. Pada siklus II, pelaksanaan tindakan juga dilakukan selama tiga kali pertemuan dengan rincian dua kali pertemuan untuk pelaksanaan tindakan dan satu kali pertemuan untuk tes akhir siklus. Pada pelaksanaan siklus II materi yang dibahas adalah sifat - sifat bangun segitiga dan persegi panjang. Untuk mengumpulkan data dalam penelitian ini digunakan metode tes. Metode tes pada hakikatnya merupakan cara pengumpulan data dengan memberikan beberapa pertanyaan atau tugas yang harus dikerjakan atau dijawab oleh 
peserta tes (testee), dan hasil dari tes tersebut berupa skor atau data yang bersifat interval.Tes dalam penelitian ini digunakan untuk mengukur hasil belajar Matematika siswa kelas V semester genap SD Negeri 5 Subagan pada tahun pelajaran 2016/2017 setelah penerapan model pembelajaran tutor sebaya. Tes tersebut berupa butir-butir soal sesuai dengan materi yang telah diajarkan. Agar butir-butir soal dapat mengukur tujuan pembelajaran yang diharapkan maka perlu dibuatkan kisi-kisi soal. Setelah data dalam penelitian terkumpul, selanjutnya dilakukan analisis data. Dalam menganalisis data ini digunakan metode analisis deskriptif kuantitatif. Agung (2010a:8) menyatakan pengertian metode analisis deskriptif kuantitatif adalah suatu cara pengolahan data yang dilakukan dengan jalan menyusun secara sistematis dalam bentuk angka-angka dan atau persentase, mengenai keadaan suatu objek yang diteliti, sehingga diperoleh kesimpulan umum.

Dalam penelitian ini, hasil belajar siswa pada saat pembelajaran Matematika dianggap berhasil apabila kriteria tingkat penguasaan siswa diatas KKM yang ditetapkan sekolah yaitu lebih dari atau sama dengan 70. Apabila nilai hasil belajar siswa lebih dari atau sama dengan 70, maka siswa dalam belajar dinyatakan "Tuntas". Namun sebaliknya apabila siswa memperoleh nilai hasil belajar dibawah 70, maka siswa dinyatakan "Tidak Tuntas".

Setelah data dalam penelitian terkumpul, selanjutnya dilakukan analisis data. Dalam menganalisis data ini digunakan metode analisis deskriptif kuantitatif. Agung (2010a:8) menyatakan pengertian metode analisis deskriptif kuantitatif adalah "suatu cara pengolahan data yang dilakukan dengan jalan menyusun secara sistematis dalam bentuk angka-angka dan atau persentase, mengenai keadaan suatu objek yang diteliti, sehingga diperoleh kesimpulan umum". Untuk menentukan tingkat tinggi-rendahnya pencapaian nilai karakter dalam pembelajaran matematika, dilakukan dengan membandingkan angka rata-rata persen (M\%) dengan kriteria Penilaian Acuan Patokan (PAP) skala lima. Dalam penelitian ini, pencapaian nilai karakter siswa pada saat pembelajaran matematika dianggap berhasil apabila kriteria tingkat penguasaan pencapaian nilai karakter siswa sudah mencapai kategori 'baik' yaitu pada interval tingkat penguasaan lebih dari atau sama dengan $80 \%-89 \%$.

Kriteria yang digunakan untuk menunjukkan keberhasilan penelitian tindakan kelas ini adalah terjadinya peningkatan hasil belajar Matematika. Peningkatan hasil belajar siswa diharapkan berada di atas KKM yang ditetapkan sekolah yaitu lebih dari atau sama dengan 70 dengan kategori "Tuntas".

\section{HASIL DAN PEMBAHASAN}

Berdasarkan hasil pencatatan dokumen diketahui bahwa nilai rata-rata ulangan harian siswa berturut-turut 64,70, 65,00, dan 63,00. Ketiga nilai tersebut berada dibawah standar Kriteria Ketuntasan Minimal (KKM) yaitu 70. Hal tersebut ditunjukkan dari nilai ulangan harian siswa pada awal semester genap tahun 2016/2017. Permasalahan tersebut, tampaknya diperlukan sebuah model pembelajaran yang inovatif dan mampu menumbuhkan hubungan sosial antar siswa sehingga hasil belajar siswa dapat ditingkatkan. Salah satunya dengan menerapkan model pembelajaran yang inovatif yang cocok digunakan dalam mata pelajaran Matematika adalah model pembelajaran tutor sebaya.

Hasil

Untuk mengetahui hasil belajar Matematika setelah diterapkan model pembelajaran tutor sebaya pada siklus I, maka dilaksanakan tes evaluasi dan tes akhir siklus. Tes evaluasi dilaksanakan setiap akhir pertemuan, sedangkan tes akhir siklus dilaksanakan setiap akhir dari siklus yang dilaksanakan. Tes akhir siklus I ini dilaksanakan pada Jumat, 24 Maret 2017. Setelah melakukan tes akhir siklus I didapatkan rata-rata hasil belajar siswa 66,52dengan kategori 'cukup'. Walaupun kategori rata-rata persentase hasil belajar Matematika pada siklus I sudah memenuhi kriteria keberhasilan, tetapi rata-rata hasil belajar Matematika pada siklus I ini belum berada di atas KKM yang ditetapkan di sekolah yaitu 70. Selain itu, ada 18 orang siswa yang nilai hasil belajarnya masih di bawah KKM dan 15 orang yang sudah berada di atas KKM atau Tuntas. 
Setelah melakukan observasi kemudian dilanjutkan dengan tahap refleksi yang dilakukan pada akhir siklus I. Dalam refleksi, peneliti bersama teman sejawat secara kolaboratif menilai dan mendiskusikan kelemahan dan kekurangan yang terdapat pada pelaksanaan tindakan siklus I untuk diperbaiki dan dilaksanakan pada tindakan siklus berikutnya. Hasil analisis terhadap hasil belajar Matematika siswa pada siklus I mencapai rata-rata 66,52. Dengan demikian rata-rata hasil belajar Matematika siswa masih berada di bawah KKM yang ditetapkan sekolah yaitu 70 .

Berdasarkan hasil analisis terhadap nilai karakter dan hasil belajar Matematika siswa pada siklus I masih berada di bawah KKM. Untuk itu, penelitian terhadap nilai karakter dan hasil belajar Matematika siswa akan dilanjutkan pada siklus II. Untuk mengetahui hasil belajar Matematika setelah diterapkan model pembelajaran tutor sebaya pada siklus II, maka dilaksanakan tes evaluasi dan tes akhir siklus. Tes evaluasi dilaksanakan setiap akhir pertemuan, sedangkan tes akhir siklus dilaksanakan setiap akhir dari siklus yang dilaksanakan. Tes akhir siklus II ini dilaksanakan pada Selasa, 25 April 2017. Hasil belajar Matematika siswa pada siklus II ini sudah mencapai kriteria keberhasilan dan hasil belajar seluruh siswapada siklus II ini juga sudah berada di atas KKM yang ditetapkan di sekolah yaitu 70. Setelah melakukan evaluasi siklus II, peneliti melakukan refleksi. Dalam pelaksanaan pembelajaran siklus II terjadi peningkatan dari siklus sebelumnya.

Peningkatan hasil belajar Matematika setelah diterapkan model pembelajaran tutor sebaya diperoleh dengan mencari selisih rata-rata hasil belajar antara siklus yang satu dengan siklus lainnya.Peningkatan hasil belajar Matematika setelah diterapkan model pembelajaran tutor sebaya dari siklus I ke siklus II sebesar 17,42. Adapun ringkasan rata-rata persentase siklus I dan siklus II setelah diterapkan model pembelajaran tutor sebaya adalah sebagai berikut.

Tabel 1. Tabel Peningkatan Hasil Belajar

\begin{tabular}{|c|c|c|}
\hline Siklus & $\begin{array}{c}\text { Rata-rata hasil belajar } \\
\text { MATEMATIKA }\end{array}$ & Kategori \\
\hline I & 66,52 & Tidak Tuntas \\
\hline II & 83,94 & Tuntas \\
\hline
\end{tabular}

Peningkatan rata-rata persentase hasil belajar Matematika pada siklus I ke siklus II disajikan dalam grafik berikut.

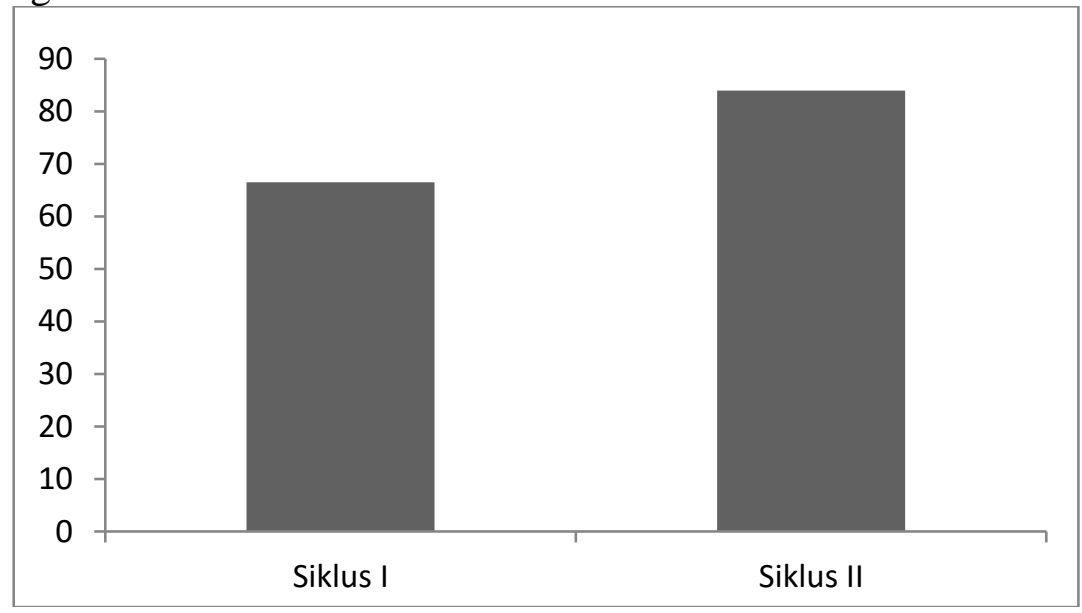

Gambar 2. Grafik Peningkatan Hasil Belajar

Hasil penelitian terhadap penerapan model pembelajaran tutor sebaya menunjukkan bahwa hasil belajar Matematika meningkat secara signifikan. Rata-rata hasil belajar siswa berturut-turut dari siklus I sampai siklus II adalah 66,52 dan 83,94. Jadi, setelah model 
pembelajaran tutor sebaya diterapkan hasil belajar Matematika meningkat dan mencapai kategori Tuntas.

\section{Pembahasan}

Hasil penelitian terhadap penerapan model pembelajaran tutor sebaya menunjukkan bahwa hasil belajar Matematika meningkat secara signifikan. Rata-rata hasil belajar siswa berturut-turut dari siklus I sampai siklus II adalah 66,52 dan 83,94. Jadi, setelah model pembelajaran tutor sebaya diterapkan hasil belajar Matematika meningkat dan mencapai kategori tuntas. Peningkatan hasil belajar Matematika seperti yang diungkapkan di atas terwujud karena model pembelajaran tutor sebaya. Model pembelajaran tutor sebaya membuat proses pembelajaran Matematika di kelas lebih menyenangkan, aktif, dan kreatif sehingga siswa termotivasi untuk belajar Matematika.

Tutor sebaya merupakan salah satu model pengelompokkan siswa dalam pembelajaran (Syaifuddin, 2007). Dengan berdiskusi secara kelompok, siswa akan terlatih dalam mengeluarkan dan menerima pendapat orang lain, jujur mengungkapkan pendapat, serta lebih bersahabat/komunikatif dengan teman satu kelompok maupun kelompok lain.

Selama pelaksanaan diskusi kelompok, masing-masing kelompok dibimbing oleh satu orang tutor. Tutor memiliki tanggung jawab membimbing anggota kelompoknya agar semua anggota kelompok mengerti. Anggota lainpun dituntut memiliki sikap demokratis untuk mengungkapkan dan menerima pendapat dari tutor maupun anggota lainnya. Peneliti bertugas sebagai observer dan memfasilitasi siswa jika dalam pelaksanaan diskusi siswa menemukan hambatan.

Selain yang diungkapkan di atas, model pembelajaran tutor sebaya juga menjadikan hasil yang cukup baik bagi siswa yang memiliki rasa takut pada guru karena dibimbing secara langsung oleh teman sebaya. Penerapan model pembelajaran tutor sebaya juga bermanfaat bagi tutor karena memperkuat konsep yang dimilikinya. Hal ini merupakan kesempatan bagi tutor untuk melatih diri dan bertanggung jawab. Selain itu, hubungan antar siswa akan bertambah erat karena model pembelajaran tutor sebaya mampu menciptakan suasana bersahabat/komunikatif.

Selama penelitian dilaksanakan di SD Negeri 5 Subagan dengan subjek siswa kelas V, penerapan model pembelajaran tutor sebaya mampu meningkatkan hasil belajar Matematika. Hasil belajar Matematika setelah diterapkan model. Jadi, jika model pembelajaran tutor sebaya diteruskan maka hasil belajar Matematika akan berada pada kategori yang lebih baik. Hal ini dikarenakan penerapan model ini sudah merupakan hasil refleksi dari penelitian ini sehingga proses pembelajaran bisa mendekati sempurna.

\section{KESIMPULAN}

Penerapan model pembelajaran tutor sebaya dapat meningkatkan hasil belajar siswa kelas V semester genap mata pelajaran Matematika SD Negeri 5 Subagan tahun pelajaran 2016/2017. Pada siklus I, rata-rata hasil belajar Matematika siswa mencapai 66,52 dan belum mencapai KKM yang ditentukan di sekolah yaitu 70. Pada siklus II terjadi peningkatan ratarata hasil belajar Matematika siswa yang mencapai dan 83,94 dan seluruh siswa sudah mencapai KKM. Peningkatan hasil belajar Matematika setelah diterapkan model pembelajaran tutor sebaya dari siklus I ke siklus II sebesar 17,42.

\section{DAFTAR PUSTAKA}

Agung, , A.A. Gede. (2010a). "Penelitian Tindakan Kelas (Teori dan Analisis Data dalam PTK)". Makalah disajikan dalam Workshop Jurusan Pendidikan Guru Sekolah Dasar. Fakultas Ilmu Pendidikan, Universitas Pendidikan Ganesha. Singaraja 27 September 2010.

(2010b). Pengantar Evaluasi Pendidikan. Singaraja: Jurusan Teknologi Pendidikan, Fakultas Ilmu Pendidikan, Universitas Pendidikan Ganesha. 
Atmadja, Nengah Bawa. (2011). "Local Genius dan Kearifan Lokal sebagai Modal Budaya dalam Pendidikan Karakter". Makalah disajikan dalam Seminar Nasional. Senat Mahasiswa Fakultas Ilmu Pendidikan, Universitas Pendidikan Ganesha.Singaraja 26 November 2011.

Departemen Pendidikan Nasional. (2006). Kurikulum Tingkat Satuan Pendidikan tentang Standar Kompetensi Mata Pelajaran Matematika Sekolah Dasar. Jakarta: Depdiknas.

Dossuwanda. (2008). "Penggunaan Metode Tutor Sebaya (contoh Proposal PTK)". Tersedia pada http://dossuwanda.wordpress.com/2008/03/11/penggunaan-metode-tutor-sebayacontoh-proposal-ptk/ (diakses tanggal 2 Februari 2017).

Sudhita, Wayan Romi. (2004). Modul Sistem Komunikasi Pendidikan. Singaraja: Jurusan Teknologi Pendidikan Fakultas Ilmu Pendidikan, IKIP Negeri Singaraja.

Suherman AS., Uman. (2011). "Pendidikan Karakter Berbasis Budaya Lokal". Makalah disajikan dalam Seminar Nasional. Senat Mahasiswa Fakultas Ilmu Pendidikan, Universitas Pendidikan Ganesha.Singaraja 26 November 2011.

Sukardi. (2003). Metodelogi Penelitian Pendidikan Kompetensi dan Praktiknya. Jakarta: PT Bumi Aksara.

Suprijono, Agus. (2009). Cooperative Learning Teori dan Aplikasi Pakem. Yogyakarta: Pustaka Pelajar.

Yahya, Yudrik. (2003). Wawasan Kependidikan. Jakarta: Departemen Pendidikan Nasional Direktorat Pendidikan Dasar dan Menengah Direktorat Tenaga Kependidikan. 